\title{
THE IMPACT OF EXPORT, IMPORT, AND RENEWABLE ENERGY CONSUMPTION ON TURKEY'S ECOLOGICAL FOOTPRINT
}

\author{
DOI: 10.17261/Pressacademia.2021.1376 \\ JEFA- V.8-ISS.1-2021(4)-p.31-38
}

\section{Betul Altay Topcu}

Kayseri University, Vocational School of Technical Sciences, Depatment of Marketing and Foreign Trade, Kayseri, Turkey. batopcu@kayseri.edu.tr, ORCID: 0000-0003-2044-4568

Date Received: January 19, $2021 \quad$ Date Accepted: March 17, 2021
To cite this document
Altay Topcu, B. (2021). The impact of export, import, and renewable energy consumption on Turkey's ecological footprint. Journal of
Economics, Finance and Accounting (JEFA), V.8(1), p.31-38.
Permanent link to this document: http://doi.org/10.17261/Pressacademia.2021.1376
Copyright: Published by PressAcademia and limited licensed re-use rights only.

\section{ABSTRACT}

Purpose - The purpose of this study is to examine the effect of export, import, and renewable energy consumption on the ecological footprint for the period 1990-2015 in Turkey.

Methodology - In this study, firstly Augmented Dickey-Fuller (ADF) and Phillips-Perron (PP) unit root tests were applied. Then, long-term relationships between variables were investigated by Johansen Cointegration Test. Finally, the long-term elasticity coefficients were estimated with the Fully Modified Ordinary Least Square (FMOLS), Dynamic Ordinary Least Squares (DOLS) and Canonical Cointegrating Regression (CCR) Models.

Findings- The ADF and PP unit root test results showed that the variables generally contain unit root at level value. When the first difference of the variables was taken, the series became stationary. The Johansen Cointegration Test findings demonstrated that there is a cointegration relationship between the variables. According to the FMOLS, DOLS and CCR models that predicted long-term elasticity coefficients, while the renewable energy consumption and export reduced the ecological footprint, the import increased the ecological footprint.

Conclusion- The analysis results showed that the variables of export and renewable energy consumption improve environmental quality in Turkey. The rate of consumption of natural resources is greater than the production rate in Turkey. This situation gradually increases the ecological deficit in the economy. The success of the economy in sustainable development depends on reducing the ecological deficit. First of all, dependency on imported resources should be reduced, and investments aimed at preserving and increasing biological capacity should be increased. In addition, priority should be given to using renewable energy rather than fossil-based energy consumption. Economic policies that can be implemented in this direction have a critical importance.

Keywords: Export, import, renewable energy consumption, ecological footprint, Turkey. JEL Codes: Q57, F18, F14

\section{INTRODUCTION}

The production model that has become widespread on a global scale in order to achieve sustainable development goals is expressed with the concept of "green economy". In the process of green economic transformation, which is a low-carbon economy, it is foreseen to protect the environment and increase competitiveness with cleaner production and eco-efficiency in production sectors (Özsoy, 2015:200).

Increasing environmental problems on a global scale caused new concepts such as eco-city, ecological energy, green certificate, eco-label and ecological footprint to be included in the literature. Ecological footprint refers to the pressure on the environment that arises as a result of human activities. It is an indicator of human impact and environmental degradation (Şimşek and Bursal, 2019:454). The concept of ecological footprint has been scientifically included in the literature since the 1990s. This concept emerged with the studies of Wackernagel and Rees after 1990 (Wackernagel 1991,1994; Rees 1992,1996; Wackernagel and Rees 1998). According to McDonald and Patterson (2004), the ecological footprint is a criterion as "carrying capacity", that is, showing how much of our existing capacity we have or could not carry to the next time period. Ecological footprint is a system designed to compare the biocapacity generated by the ecosystem in order to tolerate the consumption of biological resources by humans and the wastes generated by this consumption (Kitzes et al., 2009:1992). 
According to the definition of the World Wide Fund for Nature (WWF), the ecological footprint, which measures environmental sustainability, is expressed as biologically fertile land and water areas that are necessary to produce with the existing technology the resources that consumed by an individual or society. The ecological footprint of consumption and biological capacity are considered as two important indicators in determining the ecological footprint. The ecological footprint of consumption refers to the renewable natural resources we use to produce products consumed by society. Biological capacity is an indicator of the capacity of a geographical region to produce renewable natural resources. If the amount of ecological footprint of consumption per capita exceeds the per capita biological capacity, it means that the consumption patterns of the people living in that region cannot be sustained (WWF, 2012:6).

In Turkey, according to the WWF report, in 2007, the ecological footprint of consumption per capita is 2.7 global hectares (gha). This value corresponds to $50 \%$ more of the global biocapacity per capita. In other words, when everyone in the world consumes as much as an average Turkish citizen, we will need 1.5 planet Earth to meet the ecological footprint of consumption with natural resources. Turkey, especially in recent years because it quickly consumes natural resources according to the speed of self-renewal, it is among the ecologically debtor countries around the world. The main reason for the existence of today's biocapacity deficit in Turkey is population growth in recent years. (WWF, 2012:7).

Turkey, during the period 1961-1984 has permanently given biocapasity reserve surplus and at the end of this period, biological capacity has been equaled to the ecological footprint. During the 1984-2017 period in Turkey, the ecological footprint per capita exceeded permanently the biocapacity. In other words, the biocapacity deficit has generally increased. in 2017, biocapacity per capita was 1.4 gha, while the ecological footprint was 3.5 gha. Therefore, biocapacity deficit per capita reached 2.1 gha (Global Footprint Network, 2021). This situation shows that there is a serious environmental degradation and the renewable natural resources production capacity is running out in Turkey. Therefore, there is a need for policy implementations that will at least reduce this deficit in the country (Global Footprint Network, 2021).

In this study, it is aimed to analyze the effect of export, import and renewable energy consumption on the ecological footprint for the period 1990-2015 in Turkey. The studies using ecological footprint as dependent variable in the empirical literature have carried out recently and are still up-to-date. The study is important in terms of contributing to the current literature in this field. The study consists of five parts. Empirical literature is included in the second part of the study, following the introduction. In the third part, data set and econometric model are given. In the fourth part, empirical findings are evaluated. The fifth part discusses the results and policy preventions.

\section{LITERATURE REVIEW}

In the literatüre, a summary of the studies in which ecological footprint was used as the dependent variable is shown in Table 1. Table 1 includes studies which the ecological footprint is analyzed especially in terms of trade, export, import, renewable and non-renewable energy consumption variables.

Table 1: Literature Review on Ecological Footprint

\begin{tabular}{|c|c|c|c|c|}
\hline Author/Authors & Country/Region & Period & Methodology & Results \\
\hline Destek et al. (2018) & EU Countries & $1980-2013$ & $\begin{array}{l}\text { MG-FMOLS } \\
\text { MG-DOLS } \\
\text { DCCE-MG }\end{array}$ & $\begin{array}{l}\text { NRE increases EF, while REN and TRDO } \\
\text { decrease EF. }\end{array}$ \\
\hline $\begin{array}{l}\text { Solarin and } \\
\text { Al-Mulali } \\
\text { (2018) }\end{array}$ & 20 Countries & $1982-2013$ & AMG & $\begin{array}{l}\text { NRE and GDP cause environmental } \\
\text { degradation for all countries. }\end{array}$ \\
\hline $\begin{array}{l}\text { Ulucak and } \\
\text { Bilgili } \\
\text { (2018) }\end{array}$ & 45 Countries & $1961-2013$ & CUPFM & $\begin{array}{l}\text { the EKC Hypothesis is validated for countries } \\
\text { by income level included in the analysis. }\end{array}$ \\
\hline $\begin{array}{l}\text { Wang and } \\
\text { Dong } \\
\text { (2019) }\end{array}$ & $\begin{array}{l}14 \text { Sub-Saharan } \\
\text { African } \\
\text { countries }\end{array}$ & $1990-2014$ & AMG & $\begin{array}{l}\text { REN improves environmental quality, while } \\
\text { GDP, NRE, and URB impair environmental } \\
\text { quality. }\end{array}$ \\
\hline Dogan et al. (2019) & MINT & $1971-2013$ & Panel ARDL & $\begin{array}{l}\text { the EKC Hypothesis is valid for MINT } \\
\text { countries. NRE, URB, and FD increase EF. The } \\
\text { effects of EXP and IMP on environmental } \\
\text { degradation are negative and positive, } \\
\text { respectively. }\end{array}$ \\
\hline
\end{tabular}




\begin{tabular}{|c|c|c|c|c|}
\hline $\begin{array}{l}\text { Mikayilov } \\
\text { et al. } \\
\text { (2019) }\end{array}$ & Azerbaijan & $1996-2014$ & $\begin{array}{l}\text { Time-Varying } \\
\text { Coefficient } \\
\text { Cointegration } \\
\text { Approach }\end{array}$ & NRE and TRD increase EF. \\
\hline $\begin{array}{l}\text { Nathaniel } \\
\text { et al. } \\
\text { (2019) }\end{array}$ & South Africa & $1965-2014$ & ARDL & $\begin{array}{l}\text { URB and NRE increase environmental } \\
\text { degradation. }\end{array}$ \\
\hline $\begin{array}{l}\text { He et al. } \\
(2019)\end{array}$ & Malaysia & $1978-2013$ & ARDL & GDP, TRDO, and NRE increase EFP. \\
\hline $\begin{array}{l}\text { Langnel and } \\
\text { Amegavi (2020) }\end{array}$ & Ghana & $1971-2016$ & ARDL & $\begin{array}{l}\text { GLO, EC from fossil-fuel based energy source, } \\
\text { GDP and URB affect positively EF. }\end{array}$ \\
\hline $\begin{array}{l}\text { Nathaniel and Khan } \\
(2020)\end{array}$ & $\begin{array}{l}\text { ASEAN } \\
\text { Countries }\end{array}$ & $1990-2016$ & AMG & $\begin{array}{l}\text { the analysis results show that NRE } \\
\text { consumption, GDP, TRD increase the EF. on } \\
\text { the other hand REN consumption reduces EF } \\
\text { in across the country, however, this effect is } \\
\text { statistically insignificant. }\end{array}$ \\
\hline Apaydın (2020) & Türkiye & $1980-2014$ & $\begin{array}{l}\text { ARDL } \\
\text { FMOLS } \\
\text { DOLS }\end{array}$ & $\begin{array}{l}\text { GLO increases EFCONS, EFPROD, EFIMP. it } \\
\text { has a decreasing effect on EFEXP. Although } \\
\text { the effects of GDP on EFCONS, EFPROD, } \\
\text { EFIMP are also positive, it has a statistically } \\
\text { insignificant effect on the EFEXP. }\end{array}$ \\
\hline $\begin{array}{l}\text { Sharif et al. } \\
\text { (2020) }\end{array}$ & Türkiye & $\begin{array}{l}\text { 1965Q1- } \\
2017 Q 4 .\end{array}$ & QARDL & $\begin{array}{l}\text { REN consumption decreases EF in long term. } \\
\text { However, GDP and NRE impact positively EF } \\
\text { in long-short term. }\end{array}$ \\
\hline $\begin{array}{l}\text { Destek and } \\
\text { Sinha } \\
(2020)\end{array}$ & $\begin{array}{l}24 \text { OECD } \\
\text { Countries }\end{array}$ & $1980-2014$ & $\begin{array}{l}\text { FMOLS } \\
\text { DOLS } \\
\text { CCEMG }\end{array}$ & $\begin{array}{l}\text { While REN consumption reduces EF, NRE } \\
\text { consumption increases EF. }\end{array}$ \\
\hline $\begin{array}{l}\text { Alvarado et al. } \\
\text { (2021) }\end{array}$ & 77 Countries & $1996-2016$ & FMOLS & $\begin{array}{l}\text { the increasing R\&D, GVA-A, and TRD } \\
\text { decrease EF and increase AQ. In other words, } \\
\text { these variables decrease mitigate air and soil } \\
\text { degradation. }\end{array}$ \\
\hline Sharma et al. (2021) & $\begin{array}{l}\text { South and } \\
\text { Southeast Asia } \\
\text { Countries }\end{array}$ & $1990-2015$ & CS-ARDL & $\begin{array}{l}\text { the increased use of REN has significantly } \\
\text { reduced EF. DENS increases EF. the impact of } \\
\text { LEX on EF is found positive but insignificant. }\end{array}$ \\
\hline
\end{tabular}

Note: EFEXP: Ecological Footprint of Export; EFIMP: Ecological Footprint of Import; EFPROD: Ecological Footprint of Production; EFCONS: Ecological Footprint of Consumption; EC: Electricity Consumption; R\&D: Research and Development; AQ: Air Quality; DENS: Population Density; EF: Ecological Footprint; GVA-A: Agriculture, Forestry, and Fishing, Value Added; URB: Urbanization; GDP: Per Capita Income; REN: Renewable Energy; NRE: Non-Renewable Energy; GLO: Globalization; IMP: Import; EXP: Export; LEX: Life Expectancy; TRD: Trade; TRDO: Trade Openness, FD: Financial Development.

\section{MODEL, DATA AND ANALYSIS RESULTS}

\subsection{Estimated Model and Data Definitions}

In this study, in the case of Turkey during the period 1990-2015, the effect of export, import, and renewable energy consumption on the ecological footprint was investigated. The data and data definitions used in the analysis are shown in Table 2.

Tablo 2: Definition of Variables

\begin{tabular}{lll}
\hline Variables and Their Symbols & Measurement of Variables & Source of Data \\
\hline Ecological Footprint-EF & Global Hectares Per Capita & GFN (2021) \\
\hline Renewable Energy-REN & \% of total energy consumption & WDI (2020) \\
\hline Exports of Goods and Services-EXP & \% of GDP & WDI (2020) \\
\hline Imports of Goods and Services-IMP & \% of GDP & WDI (2020) \\
\hline
\end{tabular}

Source: Global Footprint Network-GFN, 2021; World Development Indicators-WDI, 2020. 
The natural logarithms of all variables included in the analysis are taken. The model estimated in the study is as follows:

$L E F_{i t}=\alpha+b_{1} L R E N_{i t}+b_{2} L E X P_{i t}+b_{3} L I M P_{i t}$

\subsection{Analysis Results}

In the study, ADF and PP unit root tests were applied to decide whether the series are stationary or not. After determining the existence of unit root between series, the existence of long-term relationship between variables was investigated by the Johansen Cointegration Test. The long-term elasticity coefficients of the variables were estimated with the FMOLS, DOLS, and CCR Models. The ADF test, improved by Dickey and Fuller (1981), includes the regression of its delayed value and delayed differences of the series whose stationarity is to be investigated. The equation in which the ADF test is applied is as follows:

$\Delta Y_{t}=\alpha+\beta_{t}+\delta Y_{(t-1)}+\vartheta \sum \Delta Y_{(t-1)}+\varepsilon_{t}$

In equation $2, \Delta$ is the difference processor and $\varepsilon_{t}$ is the static error term. In the unit root test, the length of the lag that will make the error term white noise for each series can be determined according to the Akaike and Schwartz information criteria. In the ADF test, the null hypothesis is that the undifferentiated series carry unit root, that is, they are not stationary. For this, in the null hypothesis, it is tested whether the coefficient $\delta$ is statistically equal to zero. The fact that the coefficient $\delta$ is statistically significant means that this hypothesis will be rejected. In this case, the series are stationary (Kızılgöl, 2006: 57).

Although the ADF test is a widely used test among unit root tests, the PP test developed by Phillips and Peron (1988) was created to eliminate the deficiencies in the ADF test. This test is differs from the ADF test in that it deals with the serial correlation and variance problem that occurs in errors. Instead of adding lagged values in order to prevent autocorrelation in the ADF equation, the authors also rearranged the $t$ statistics by estimating the DF equation. The equation for this test is as follows:

$\Delta Y_{t}=\alpha Y_{t-1}+x_{t}^{\prime} \delta+\varepsilon_{t}$

In equation $3, \alpha=\rho-1, x_{t}$ is the deterministic component expressing the "constant" or "constant and trend". In the PP test, the basic hypothesis is that there is a unit root and the hypotheses are set as $H_{0}: \alpha=0$ and $H_{1}: \alpha<0$. The asymptotic distribution of the test statistics is the same as with the ADF test. Therefore, the test statistic is compared with the MacKinnon critical values (Çağlayan and Saçaklı, 2006:124). the unit root test results of the estimated model are presented in Table 3.

Table 3: Unit Root Test Results

\begin{tabular}{|c|c|c|c|c|c|}
\hline \multirow[t]{2}{*}{ For Intercept } & \multirow[b]{2}{*}{ Variables } & \multicolumn{2}{|c|}{ ADF Test Results } & \multicolumn{2}{|c|}{ PP Test Results } \\
\hline & & Level & First Difference & Level & First Difference \\
\hline $\begin{array}{l}\text { Dependent } \\
\text { Variable }\end{array}$ & LEF & $\begin{array}{c}-0.961440 \\
(0.7507)\end{array}$ & $\begin{array}{c}-4.036530 * \\
(0.0050)\end{array}$ & $\begin{array}{c}-0.908312 \\
(0.7685)\end{array}$ & $\begin{array}{c}-4.167000^{*} \\
(0.0037)\end{array}$ \\
\hline \multirow{3}{*}{$\begin{array}{l}\text { Independent } \\
\text { Variables }\end{array}$} & LREN & $\begin{array}{c}-1.119494 \\
(0.6916)\end{array}$ & $\begin{array}{c}-6.243789^{*} \\
(0.0000)\end{array}$ & $\begin{array}{c}-1.044814 \\
(0.7207)\end{array}$ & $\begin{array}{c}-6.787178^{*} \\
(0.0000)\end{array}$ \\
\hline & LEXP & $\begin{array}{c}-2.632494 \\
(0.1006) \\
\end{array}$ & $\begin{array}{c}-4.427253^{*} \\
(0.0022)\end{array}$ & $\begin{array}{c}-2.754352 * * * \\
(0.0793) \\
\end{array}$ & $\begin{array}{c}-6.500076^{*} \\
(0.0000)\end{array}$ \\
\hline & LIMP & $\begin{array}{c}-2.226207 \\
(0.2025) \\
\end{array}$ & $\begin{array}{c}-4.398468^{*} \\
(0.0023)\end{array}$ & $\begin{array}{c}-2.072538 \\
(0.2565) \\
\end{array}$ & $\begin{array}{c}-5.252327^{*} \\
(0.0003)\end{array}$ \\
\hline \multicolumn{2}{|c|}{ For Trend and Intercept } & \multicolumn{2}{|c|}{ ADF Test Results } & \multicolumn{2}{|c|}{ PP Test Results } \\
\hline & Variables & Level & First Difference & Level & First Difference \\
\hline $\begin{array}{l}\text { Dependent } \\
\text { Variable }\end{array}$ & LEF & $\begin{array}{c}-3.165402 \\
(0.1148) \\
\end{array}$ & $\begin{array}{c}-3.947381^{* *} \\
(0.0256) \\
\end{array}$ & $\begin{array}{c}-2.531151 \\
(0.3117) \\
\end{array}$ & $\begin{array}{c}-4.001807^{* *} \\
(0.0229) \\
\end{array}$ \\
\hline \multirow{3}{*}{$\begin{array}{l}\text { Independent } \\
\text { Variables }\end{array}$} & LREN & $\begin{array}{l}-2.70413 \\
(0.2432) \\
\end{array}$ & $\begin{array}{c}-6.098187^{*} \\
(0.0002)\end{array}$ & $\begin{array}{c}-2.653246 \\
(0.2622) \\
\end{array}$ & $\begin{array}{c}-6.800184^{*} \\
(0.0001)\end{array}$ \\
\hline & LEXP & $\begin{array}{c}-2.642239 \\
(0.2666)\end{array}$ & $\begin{array}{c}-4.680365^{*} \\
(0.0057)\end{array}$ & $\begin{array}{c}-2.574347 \\
(0.2936) \\
\end{array}$ & $\begin{array}{c}-8.062677^{*} \\
(0.0000) \\
\end{array}$ \\
\hline & LIMP & $\begin{array}{c}-3.655517^{* *} \\
(0.0459)\end{array}$ & $\begin{array}{c}-4.423994^{*} \\
(0.0098)\end{array}$ & $\begin{array}{c}-2.660692 \\
(0.2594)\end{array}$ & $\begin{array}{c}-5.577353^{*} \\
(0.0007)\end{array}$ \\
\hline
\end{tabular}

Note: ${ }^{*}, *$, and $* * *$ demonstrate the statistical significance of the coefficients at $1 \%, 5 \%$, and $10 \%$ levels, respectively. Values in parentheses represent the probability values of coefficients. 
After examining the stationary properties of the variables, it was investigated whether there is a long-term relationship between these variables by the Johansen cointegration method. Johansen (1988) and Johansen and Juselius (1990) use the maximum eigen value and trace statistics to determine the the existence of this relationship. These tests can be expressed as in equation 4 and 5 :

$J_{\text {trace }}=-T \sum_{i=r+1}^{n} \ln \left(1-\gamma_{i}\right)$

$J_{\max }=-T \ln \left(1-\gamma_{r+1}\right)$

In equations 4 and 5, $T$ is the sample size and $\gamma_{i}$ is the largest canonical relationship. In the maximum eigen value test, the existence of at most $r$ cointegration vectors is tested against the alternative hypothesis claiming the existence of $r+1$ cointegration vector. On the other hand, in the trace test, the presence of at most $r$ cointegration vector is tested against the alternative hypothesis that claims the existence of at least $r+1$ cointegration vector (Sinan, 2018:688; Özcan and Arı, 2013:111).

In the study, before the cointegration test, the most appropriate lag length was determined by running the VAR process among the variables. Accordingly, 2 delay lengths were chosen as the optimal delay length. In this framework, the results of the Johansen Cointegration test are shown in Table 4.

Table 4: Johansen Cointegration Test Results

\begin{tabular}{|c|c|c|c|c|c|}
\hline \multicolumn{6}{|c|}{ Trace Test Results* } \\
\hline & $\begin{array}{c}H_{0} \\
\text { Hypothesis }\end{array}$ & Eigenvalue & $\begin{array}{c}\text { Trace } \\
\text { Statistic }\end{array}$ & $\begin{array}{c}\text { Critical Value } \\
(5 \%)\end{array}$ & $\begin{array}{l}\text { Prob } \\
\text { Value }\end{array}$ \\
\hline $\mathrm{r}=0^{*}$ & None* & 0.787433 & 67.72297 & 47.85613 & 0.0003 \\
\hline$r \leq 1^{*}$ & At most $1^{*}$ & 0.620016 & 32.10749 & 29.79707 & 0.0266 \\
\hline$r \leq 2$ & At most 2 & 0.280331 & 9.852110 & 15.49471 & 0.2923 \\
\hline$r \leq 3$ & At most 3 & 0.094609 & 2.285937 & 3.841466 & 0.1305 \\
\hline \multicolumn{6}{|c|}{ Max Eigen-Value Test Results** } \\
\hline & $\begin{array}{c}H_{0} \\
\text { Hypothesis }\end{array}$ & Eigenvalue & $\begin{array}{c}\text { Max Eigen } \\
\text { Statistic }\end{array}$ & $\begin{array}{c}\text { Critical Value } \\
(5 \%)\end{array}$ & $\begin{array}{l}\text { Prob } \\
\text { Value }\end{array}$ \\
\hline $\mathrm{r}=0^{*}$ & None* & 0.787433 & 35.61547 & 27.58434 & 0.0038 \\
\hline$r \leq 1^{*}$ & At most $1^{*}$ & 0.620016 & 22.25538 & 21.13162 & 0.0346 \\
\hline$r \leq 2$ & At most 2 & 0.280331 & 7.566173 & 14.26460 & 0.4245 \\
\hline$r \leq 3$ & At most 3 & 0.094609 & 2.285937 & 3.841466 & 0.1305 \\
\hline
\end{tabular}

Table 4 shows the trace and maximum eigen value test statistics. In the hypotheses section, tests are carried out with the numbers of cointegrated equations. The hypotheses are as follows: first hypothesis there is no cointegrated vector, second hypothesis there is at most 1 cointegrated vector, third hypothesis there are at most 2 cointegrated vectors. As seen in Table 4 , the trace and eigen value statistics for the first and second hypotheses are higher than the critical value. According to the both test results, the first hypothesis is rejected at the $5 \%$ significance level and the second hypothesis is accepted. In other words, all test results show that there are two long-term vector relationships between variables. According to this result, it is concluded that there is a significant long-term relationship between the ecological footprint and export, import, and renewable energy consumption.

After finding the cointegration relationship between the variables, the long-term elasticity coefficients of the series were estimated using FMOLS, DOLS and CCR Models. Estimation results are shown in Table 5. According to the FMOLS, DOLS and CCR estimation results, a $1 \%$ increase in LREN causes to a decrease in LEF $0.31 \%, 0.27 \%$ and $0.31 \%$, respectively. In other words, the renewable energy consumption has a negative impact on Turkey's ecological footprint, and this effect is statistically meaningful at $1 \%$ significance level.

On the other hand, according to the all estimation results, a $1 \%$ increase in LEXP causes to a decrease in LEF $0.21 \%, 0.40 \%$ and $0.24 \%$, respectively. In other words, export of goods and services has a negative effect on Turkey's ecological footp rint. While this effect is statistically meaningful at $5 \%$ significance level according to the FMOLS and CCR estimation results, it is statistically meaningful at $1 \%$ significance level according to the DOLS estimation result. 
the another result obtained from the models of FMOLS, DOLS, and CCR is that the import of goods and services increases Turkey's ecological footprint at $1 \%$ significance level. It is concluded that a $1 \%$ increase in LIMP among these models causes to an increase in LEF $0.35 \%, 0.58$ and $0.39 \%$, respectively. The results obtained in the analysis are consistent with the theoretical and empirical literature.

\section{Table 5: Estimation Results}

\begin{tabular}{cccc}
\hline & \multicolumn{3}{c}{ Dependent Variable: LEF } \\
\hline & \multicolumn{2}{c}{ Methods } & CCR \\
\hline $\begin{array}{c}\text { Independent } \\
\text { Variables }\end{array}$ & Coefficients & DOLS & Coefficients \\
\hline LREN & & Coefficients & \\
& $-0.314526^{*}$ & $-0.274063^{*}$ & $-0.317030^{*}$ \\
& $(0.0000)$ & $(0.0000)$ & $(0.0000)$ \\
\hline LEXP & $-0.210106^{* *}$ & $-0.401018^{*}$ & $-0.248875^{* *}$ \\
& $(0.0174)$ & $(0.0000)$ & $(0.0204)$ \\
\hline LIMP & $0.355959^{*}$ & $0.584305^{*}$ & $0.390855^{*}$ \\
& $(0.0011)$ & $(0.0000)$ & $(0.0018)$ \\
\hline C & $0.629734^{*}$ & $0.520305^{*}$ & $0.636493^{*}$ \\
& $(0.0013)$ & $(0.0010)$ & $(0.0010)$ \\
\hline$R^{2}$ & 0.824564 & 0.984617 & 0.818114 \\
\hline
\end{tabular}

Note: ${ }^{*}$ and ${ }^{* *}$ indicate the statistical significance of the coefficients at $1 \%$ and $5 \%$ significance levels, respectively. Values in parentheses represent the probability values of coefficients.

\section{CONCLUSION AND POLICY RECOMMENDATIONS}

Emphasizing the concept of ensuring the continuity of life and leaving a sustainable environment to future generations, the ecological footprint measures the biological capacity required to reproduce the consumed natural resources and to neutralize the waste generated. Biological capacity is an indicator of a region's capacity to produce natural resources. In this study, in Turkey the relationship between the ecological footprint, export, import, and renewable energy consumption was examined for the 1990-2015 period. According to the findings of the study in which the ecological footprint is used as the dependent variable, the export and renewable energy consumption in the said period reduce the ecological footprint, while the import has an increasing impact on the ecological footprint.

In general, studies in the empirical literature examine the effect of trade variable or trade openness variable on ecological footprint. Findings obtained in these studies show that the trade variable raises the ecological footprint. In this study, the effects of export and import flows on the ecological footprint were examined separately. The findings obtained are consistent with the study of Dogan et al. (2019). In addition, considering that worldwide import flows are more than export flows, the results obtained in the study are consistent with the studies of He et al. (2019), Nathaniel and Khan (2020) and Mikayilov et al. (2019), which examine the effect of trade on the ecological footprint. Findings obtained in all studies including renewable energy consumption revealed that this variable reduces the ecological footprint. In this respect, the study is consistent with the literature reviewed.

Due to the consumption rate of natural resources is greater than the rate of production in Turkey, Turkey's ecological deficit has grown steadily. According to the WWF report 2012, the ecological footprint of consumption per capita in Turkey is equal to the world average, while the biological capacity per capita is below the world average. This situation shows that the people living in Turkey have a higher the ecological debt than the world average. Since 1989, in Turkey, imported from abroad, the amount of natural resources are more than the amount of natural resources are exported. Therefore, Turkey's ecological trade deficit has increased and this situation has caused it to be a biological capacity importer.

It is required policies reducing ecological deficit to achieve success in sustainable development in Turkey. For this, it is an inevitable process to reduce dependence on imported resources and to increase investments aimed at preserving and increasing biological capacity. Biodiversity should be protected with sustainable environmental policies that ensure the continuity of economic activities. Moreover, priority should be given to the use of renewable energy rather than fossil-based energy consumption, and efforts to increase awareness in environmental policies should be spread to large segments of the society and public awareness on this issue should be raised. 
In Turkey, as in all over the world the energy sector needs to be decarbonised in an economically, environmentally and socially sustainable manner. This will both reduce the economy's dependence on external resources and offset the increase in the ecological footprint. Although the investment cost to be made in the renewable energy sector is high in the first place, there is a need for income to meet that cost. In this respect, encouraging to increase export which is the most important source of economic growth and most of the revenues generated from this are directed towards the renewable energy sector is an inevitable process of reducing the ecological deficit in Turkey.

\section{REFERENCES}

Alvarado, R., Ortiz, C., Jimenez, N., Ochoa-Jimenez, D., \& Tillaguango, B. (2021). Ecological Footprint, Air Quality and Research and Development: The Role of Agriculture and International Trade. Journal of Cleaner Production, 288, 1-13. DOI: 10.1016/j.jclepro.2020.125589

Apaydın, Ş. (2020). Küreselleşmenin Ekolojik Ayak İzi Üzerindeki Etkileri: Türkiye Örneği. Ekonomi, Politika \& Finans Araştırmaları Dergisi, 5(1), 23-42. DOI: $10.30784 /$ epfad.695836

Çağlayan, E., \& Saçaklı, N. (2006). Satın Alma Gücü Paritesinin Geçerliliğinin Sıfır Frekansta Spektrum Tahmincisine Dayanan Birim Kök Testleri ile İncelenmesi. Atatürk Üniversitesi iïBF Dergisi, 20(1), 121-137.

Destek, M.A., \& Sinha, A. (2020). Renewable, Non-Renewable Energy Consumption, Economic Growth, Trade Openness and Ecological Footprint: Evidence From Organisation for Economic Co-Operation and Development Countries. Journal of Cleaner Production, 242 , 1-11. DOI: $10.1016 / j$.jclepro.2019.118537

Destek, M.A., Ulucak, R. \& Dogan, E. (2018). Analyzing The Environmental Kuznets Curve for the EU Countries: the Role of Ecological Footprint. Environmental Science and Pollution Research. 25, 29387-29396. DOI:10.1007/s11356-018-2911-4

Dickey, D.A. and Fuller, W.A. (1981). Distribution of the Estimators for Autoregressive Time Series With a Unit Root, Econometrica, 49(4), 1057-1072. DOI: 10.2307/1912517

Dogan, E., Taspinar, N., \& Gokmenoglu, K.K. (2019). Determinants of Ecological Footprint in MINT Countries. Energy \& Environment, 30(6), 1065-1086. DOI: 0958305X19834279

Global Footprint Network (2021). National Footprint and Biocapacity Accounts. https://data.footprintnetwork.org/, accessed 20 January 2021.

He, F.S., Gan, G.G.G., Al-Mulali, U., \& Solarin, S.A. (2019). The Influences of Economic Indicators on Environmental Pollution in Malaysia. International Journal of Energy Economics and Policy, 9(2), 123-131. DOI: 10.32479/ijeep.7489

Johansen, S. (1988). Statistical Analysis of Cointegration Vectors. Journal of Economic Dynamics and Control, 12 (2-3), 231-254. DOI: 10.1016/0165-1889(88)90041-3

Johansen, S., \& Juselius, K. (1990). Maximum Likelihood Estimation and Iference On Cointegration With Applications to the Demand for Money. Oxford Bulletin of Economics and Statistics, 52 (2), 169-210. DOI: 10.1111/j.1468-0084.1990.mp52002003.x

Kızılgöl, Ö. (2006). Türkiye'de Büyüme Oranı İle İşsizlik Oranı Arasındaki İlişki. Yönetim ve Ekonomi Araştırmaları Dergisi, 4(6), 54-69.

Kitzes J., Galli A., Bagliani M., Barrett J., Dige G., Ede S., Erb K., Giljum S., Haberl H., Hails C., Jolia-Ferrier L., Jungwirth S., Lenzen M., Lewis K., Loh J., Marchettini N., Messinger H., Milne K., Moles R., Monfreda C., Moran D., Nakano K., Pyhälä A., Rees W., Simmons C., Wackernagel M., Wada Y., Walsh C., \& Wiedmann T. (2009). A Research Agenda for Improving National Ecological Footprint Accounts. Ecological Economics, 68(7), 1991-2007. DOI: 10.1016/j.ecolecon.2008.06.022

Langnel, Z., \& Amegavi, G.B. (2020). Globalization, Electricity Consumption and Ecological Footprint: An Autoregressive Distributive Lag (ARDL) Approach. Sustainable Cities and Society, 63, 1-12. DOI: 1016/j.scs.2020.102482

McDonald, G.W., \& Patterson, M.G. (2004). Ecological Footprints and Interdependencies of Newzealand Regions. Ecological Economics, 50, 49-67. DOI: 10.1016/j.ecolecon.2004.02.008

Mikayilov, J.I., Mukhtarov, S., Mammadov, J., \& Azizov, M. (2019). Re-Evaluating the Environmental Impacts of Tourism: Does EKC Exist?. Environmental Science and Pollution Research, 26, 1-14. DOI: 10.1007/s11356-019-05269-w

Nathaniel, S., \& Khan, S.A.R. (2020). The Nexus Between Urbanization, Renewable Energy, Trade, and Ecological Footprint in ASEAN Countries, Journal of Cleaner Production, 272, 1-9. 122709 DOI: 10.1016/j.jclepro.2020.122709

Nathaniel, S., Nwodo, O., Adediran, A., Sharma, G., Shah, M., \& Adeleye, N. (2019). Ecological Footprint, Urbanization, and Energy Consumption in South Africa: Including the Excluded. Environmental Science and Pollution Research, 26(30), 1-12. DOI: 10.1007/s11356-01905924-2

Özcan, B., \& Arı, A. (2013). Para Talebinin Belirleyenleri ve İstikrarı Üzerine Bir Uygulama: Türkiye Örneği. Yönetim ve Ekonomi, 20(2), 105120. 
Özsoy, C.E. (2015). Düşük Karbon Ekonomisi ve Türkiye'nin Karbon Ayak İzi. Uluslararası Emek ve Toplum Dergisi, 4(9), $198-215$.

Phillips, P.C.B, \& Perron, P. (1988). Testing for a Unit Root in Time Series Regression. Biometrika, 75(2), 335-346. DOI: 10.1093/biomet/75.2.335

Rees W.E. (1992). Ecological Footprints and Appropriated Carrying Capacity: What Urban Economics Leaves Out. Environment and Urbanization, 4(2), 121-130. DOI: 10.1177/095624789200400212

Rees W.E. (1996). Revisiting Carrying Capacity: Area-Based Indicators of Sustainability. Population and Environment, 17(3), 195-215. DOI: 10.1007/BF02208489

Sinan, O.B. (2018). Türkiye'de İşsizlik Oranları ile Uluslararası Petrol Fiyatları İlişkisi: 1980-2016. Finans Ekonomi ve Sosyal Araştırmalar Dergisi (FESA), 3(4), 681-695. DOI: 10.29106/fesa.453091

Sharif, A., Tuzemen, Ö.B., Uzuner, G., Ozturk, I., \& Sinha, A. (2020). Revisiting the Role of Renewable and Non-Renewable Energy Consumption on Turkey's Ecological Footprint: Evidence from Quantile ARDL Approach. Sustainable Cities and Society, 57, 1-12. DOI: $10.1016 /$ j.scs.2020.102138

Sharma, R., Sinha, S., \& Kautish, P. (2021). Does Renewable Energy Consumption Reduce Ecological Footprint? Evidence From Eight Developing Countries of Asia, Journal of Cleaner Production, 285, 1-13. DOI: 10.1016/j.jclepro.2020.124867

Solarin, S.A., \& Al-Mulali, U. (2018). Influence of Foreign Direct İnvestment on Indicators of Environmental Degradation. Environmental Science and Pollution Research, 25(25), 24845-24859. DOI: 10.1007/s11356-018-2562-5

Şimşek, T., \& Bursal, M. (2019). Türkiye'de Ekolojik Ayak İzi ve Biyokapasite Arasındaki İlişki: Bootstrap Rolling Window Nedensellik Testi. IBAD Sosyal Bilimler Dergisi, Özel Sayı, 452-465. 10.21733/ibad.613865

Ulucak, R., \& Bilgili, F. (2018). A Reinvestigation of EKC Model by Ecological Footprint Measurement for High, Middle and Low Income Countries. Journal of Cleaner Production, 188, 144-157. DOI: 10.1016/j.jclepro.2018.03.191

Wackernagel M. (1991). Using Appropriated Carrying Capacity'as An Indicator: Measuring the Sustainability of A Community. The UBC Task Force On Healthy And Sustainable Communities, UBC School of Community and Regional Planning, Vancouver.

Wackernagel M. (1994). Ecological Footprint and Appropriated Carrying Capacity: A Tool for Planning Toward Sustainability. PhD Thesis, University of British Columbia.

Wackernagel M., \& Rees W. (1998). Our Ecological Footprint: Reducing Human Impact on the Earth. New Society Publishers, Philadelphia, 785. DOI: $10.5070 / \mathrm{G} 31710273$.

Wang, J., \& Dong, K. (2019). What Drives Environmental Degradation? Evidence from 14 Sub-Saharan African countries. Science of the Total Environment, 656, 165-173. DOI: 10.1016/j.scitotenv.2018.11.354

World Bank (2020), World Development Indicators Data Bank. https://databank.worldbank.org/, accessed 15 January 2021.

WWF (2012). Türkiye'nin Ekolojik Ayak İzi Raporu. 